\title{
Development of a mixed feed strategy for a recombinant Pichia pastoris strain producing with a de-repression promoter
}

\author{
Simona Capone, Jernej Horvat, Christoph Herwig and Oliver Spadiut ${ }^{*}$
}

\begin{abstract}
Background: Recombinant protein production in the yeast Pichia pastoris is usually based on the alcohol oxidase promoters PAOX 1 and PAOX2, which are regulated by methanol and strongly repressed by other C-sources, like glycerol and glucose. However, the use of methanol brings several disadvantages, which is why current trends in bioprocess development with P. pastoris are focussing on minimizing the required amount of methanol or even avoid its employment. In this respect novel promoter systems which do not rely on methanol have been investigated and promoter variants were designed to fine-tune gene expression. Amongst these novel promoter systems, mutated AOX promoters, which are regulated by available carbon source concentration (so-called de-repressed promoters), are currently raising attention. However, the main disadvantage of such a production system is that expression and growth usually cannot happen concomitantly resulting in low space-time-yields.
\end{abstract}

Results: Here we show the development of a mixed-feed strategy for an industrial recombinant P. pastoris de-repression strain aiming at increased productivity and maximum space-time-yield. By doing dynamic experiments we determined a ratio between the specific substrate uptake rates of glycerol and sorbitol allowing a more than 2-fold increased productivity compared to the conventional single substrate de-repression strategy.

Conclusion: Based on our results we recommend adjusting $\mathrm{q}_{\text {s glycerol }}=0.04 \mathrm{~g} \mathrm{~g}^{-1} \mathrm{~h}^{-1}$ and $\mathrm{q}_{\mathrm{s} \mathrm{sorbitol}}=0.055 \mathrm{~g} \mathrm{~g}^{-1} \mathrm{~h}^{-1}$ to obtain highest productivity with a P. pastoris de-repression strain. Our methodological approach of designing mixed-feed strategies based on physiological strain characterization using dynamic experiments proved to be beneficial.

Keywords: Pichia pastoris, Mutated AOX1 promoter, De-repression, Phospholipase C, Glycerol, Sorbitol, Mixed feed, Productivity

\section{Background}

The methylotrophic yeast Pichia pastoris is widely used for recombinant protein production in industrial biotechnology. Recombinant protein production in this yeast is usually based on the transcriptional activity of the alcohol oxidase promoters pAOX1 and pAOX2, which are regulated by methanol and strongly repressed by other C-sources, like glycerol and glucose [1]. However, the use of methanol brings several disadvantages as methanol

\footnotetext{
*Correspondence: oliver.spadiut@tuwien.ac.at

Institute of Chemical Engineering, Research Area Biochemical

Engineering, Vienna University of Technology, Gumpendorfer Strasse 1a,
} 1060 Vienna, Austria metabolism causes heat production and increased need of oxygen, on-line methanol monitoring and especially feedback control is difficult and methanol accumulation leads to the production of toxic compounds [2]. Consequently, current trends in bioprocess development with $P$. pastoris are focussing on minimizing the required amount of methanol.

Bioprocesses employing P. pastoris can on the one hand be improved by developing mixed feed strategies, where a primary C-source (e.g. glycerol) is used for biomass growth in non-repressing concentrations, whereas methanol is used for induction [2-4]. In this respect, positive effects of mixed-feed strategies on productivity have been 
demonstrated for both P. pastoris $\mathrm{Mut}^{\mathrm{S}}$ and $\mathrm{Mut}^{+}$strains [5]. To analyze the benefit of a mixed-feed strategy on productivity in more detail, recent studies are aiming at a better understanding of its impact on cell physiology by performing metabolomics and metabolic flux analysis $[2,6]$. In a recent study, we were able to show considerable improvement by determining the specific substrate uptake rates $\left(\mathrm{q}_{\mathrm{s}}\right)$ and employing dynamic experiments to examine physiological conditions allowing high productivity in a methanol-glycerol mixed feed environment [7]. However, even in these mixed feed systems methanol is still required for induction making it less attractive for industrial large-scale production processes.

Besides bioprocess engineering approaches, also strain engineering can be applied to minimize or even avoid the use of methanol as inducer. Novel promoter systems which do not rely on methanol have been investigated and promoter variants were designed to fine-tune gene expression [8-11]. Amongst these novel promoter systems, mutated AOX promoters, which are regulated by carbon source depletion (so-called de-repressed promoters), are currently raising attention $[8,12]$. These promoter systems are especially interesting for bioreactor cultivations, where substrate concentrations can be tightly controlled at levels allowing full promoter derepression. However, the main disadvantage of such a production system is that expression and growth usually cannot happen concomitantly. Thus, a typical bioprocess with these systems usually comprises three steps: (1) batch, (2) repressed fed-batch at a high growth rate, and (3) de-repressed fed-batch at limited carbon source concentration for production. Thus, space-time-yields (STY) with these systems are typically rather low.

In the present study we physiologically characterized an industrial $P$. pastoris strain harbouring the recombinant product phospholipase C (PLC) from Bacillus cereus under the control of a mutated AOX1 promoter, which gets de-repressed at limiting concentrations of glycerol. Due to high structural and catalytic similarity of PLC from B. cereus with mammalian PLCs, it is currently used as a good model system and is thus a highly important subject in medical research [13]. Since this enzyme is hard to produce, the current price for an enzyme preparation from $B$. cereus lies at 320 Euros for 5 Units, which corresponds to only $5 \mu \mathrm{g}$ of protein (P5542-5UN; Sigma Aldrich).

Based on physiological parameters, we cultivated the recombinant $P$. pastoris strain under optimized conditions following the typical feeding regime for such derepressed strains comprising of the three phases (1) batch, (2) repressed fed-batch at high $\mathrm{q}_{\mathrm{s} \text { glycerol }}$ and (3) derepressed fed-batch at low $\mathrm{q}_{\mathrm{s} \text { glycerol. }}$. However, our main goal was the development of a mixed feed strategy for this strain aiming at increased productivity and a higher STY. Thus, we also propose a novel methodology to develop a mixed-feed strategy for industrial recombinant $P$. pastoris de-repression strains using dynamic experiments.

\section{Methods}

\section{Microorganism}

A P. pastoris CBS7435 $\mathrm{Mut}^{\mathrm{S}}$ strain carrying the recombinant gene for phospholipase $\mathrm{C}$ from Bacillus cereus (PLC; EC 3.1.4.3) under the control of a mutated AOX1 promoter, conferring high expression upon de-repressing conditions (i.e. at limiting glycerol concentrations), was kindly provided by VTU Technology GmbH (Grambach, Austria). This strain will be referred to as "recombinant $P$. pastoris de-repression strain" in this article.

\section{Culture media}

Precultures were done in yeast nitrogen base medium (YNB; $0.1 \mathrm{M}$ potassium phosphate buffer $\mathrm{pH}$ 6.0, $3.4 \mathrm{~g} \mathrm{~L}^{-1} \mathrm{YNB}$ w/o amino acids and ammonia sulfate, $10 \mathrm{~g} \mathrm{~L}^{-1}\left(\mathrm{NH}_{4}\right)_{2} \mathrm{SO}_{4}, 400 \mathrm{mg} \mathrm{L}^{-1}$ biotin, $20 \mathrm{~g} \mathrm{~L}^{-1}$ glucose). Zeocine was added to a concentration of $100 \mu \mathrm{g} \mathrm{L}^{-1}$.

Batch and fed-batch cultivations were performed in 2-fold concentrated basal salt medium (BSM; $21.6 \mathrm{~mL} \mathrm{~L}^{-1}$ $85 \%$ phosphoric acid, 0.36 g L L $\mathrm{CaSO}_{4} \cdot 2 \mathrm{H}_{2} \mathrm{O}$, $27.24 \mathrm{~g} \mathrm{~L}^{-1} \mathrm{~K}_{2} \mathrm{SO}_{4}, 4.48 \mathrm{~g} \mathrm{~L}^{-1} \mathrm{MgSO}_{4} \cdot 7 \mathrm{H}_{2} \mathrm{O}, 8.26 \mathrm{~g} \mathrm{~L}^{-1}$ $\mathrm{KOH}, 0.3 \mathrm{~mL} \mathrm{~L}^{-1}$ Antifoam Struktol J650, $4.35 \mathrm{~mL} \mathrm{~L}^{-1}$ PTM1, $\mathrm{NH}_{4} \mathrm{OH}$ as $\mathrm{N}$-source). Trace element solution (PTM1) was made of $6.0 \mathrm{~g} \mathrm{~L}^{-1} \mathrm{CuSO}_{4} \cdot 5 \mathrm{H}_{2} \mathrm{O}, 0.08 \mathrm{~g} \mathrm{~L}^{-1}$ $\mathrm{NaI}, 3.0 \mathrm{~g} \mathrm{~L}^{-1} \mathrm{MnSO}_{4} \cdot \mathrm{H}_{2} \mathrm{O}, 0.2 \mathrm{~g} \mathrm{~L}^{-1} \mathrm{Na}_{2} \mathrm{MoO}_{4} \cdot 2 \mathrm{H}_{2} \mathrm{O}$, $0.02 \mathrm{~g} \mathrm{~L}^{-1} \mathrm{H}_{3} \mathrm{BO}_{3}, 0.5 \mathrm{~g} \mathrm{~L}^{-1} \mathrm{CoCl}_{2}, 20.0 \mathrm{~g} \mathrm{~L}^{-1} \mathrm{ZnCl}_{2}$, $65.0 \mathrm{~g} \mathrm{~L}^{-1} \mathrm{FeSO}_{4} \cdot 7 \mathrm{H}_{2} \mathrm{O}, 0.2 \mathrm{~g} \mathrm{~L}^{-1}$ biotin, $5 \mathrm{~mL} \mathrm{~L}^{-1} \mathrm{H}_{2} \mathrm{SO}_{4}$. The concentration of the base $\mathrm{NH}_{4} \mathrm{OH}$ was determined by titration with $0.25 \mathrm{M}$ potassium hydrogen phthalate.

\section{Bioreactor cultivations \\ Preculture}

Frozen stocks $\left(-80^{\circ} \mathrm{C}\right)$ were cultivated in $100 \mathrm{~mL}$ YNBZeocine in $1,000 \mathrm{~mL}$ shake flasks at $30^{\circ} \mathrm{C}$ and $230 \mathrm{rpm}$ for $24 \mathrm{~h}$. Then, the preculture was transferred aseptically to the culture vessel. The inoculum volume was $10 \%(\mathrm{v} / \mathrm{v})$ of the final starting volume.

\section{Batch and fed-batch cultivations}

Batch and fed-batch cultivations were carried out in a $5 \mathrm{~L}$ working volume glass bioreactor (Infors, Switzerland). Dissolved oxygen $\left(\mathrm{dO}_{2}\right)$ was measured with a sterilizable fluorescence dissolved oxygen electrode (Visiferm DO425, Hamilton, Germany). The $\mathrm{pH}$ was measured with a sterilizable electrode (Easyferm ${ }^{\mathrm{Tw}}$, Hamilton, Switzerland) and maintained constant at $\mathrm{pH} 5.0$ with a PID controller using $\mathrm{NH}_{4} \mathrm{OH}(2-3 \mathrm{M})$. Base consumption was determined gravimetrically. Cultivation temperature was 
set to $30^{\circ} \mathrm{C}$ and agitation was fixed to $1,000 \mathrm{rpm}$. The culture was aerated with $2.0 \mathrm{vvm}$ dried air to keep dissolved oxygen level above $30 \%$. In case of $\mathrm{dO}_{2}$ limitation pure oxygen was added. Off-gas was measured by an infrared cell for $\mathrm{CO}_{2}$ and a zirconium dioxide sensor for $\mathrm{O}_{2}$ concentration (DasGip, Germany). Temperature, $\mathrm{pH}, \mathrm{dO}_{2}$, agitation as well as $\mathrm{CO}_{2}$ and $\mathrm{O}_{2}$ in the off-gas were measured online and logged in a process information management system (PIMS; Lucullus, Biospectra, Switzerland).

Before fed-batch experiments, a single dynamic batch cultivation with substrate pulses was performed, as we described previously [14-16], to determine the 2nd $\mathrm{C}$-source for the development of a mixed feed strategy. After the complete consumption of glucose at a concentration of $40 \mathrm{~g} \mathrm{~L}^{-1}$ in the batch, the C-sources glucose, sorbitol, mannose, fructose, maltose, glycerol and lactic acid were sequentially pulsed twice to the culture each in a final concentration of $45 \mathrm{mM}$. For each pulse, at least two samples were taken for offline sample analysis to calculate specific rates and yields.

Fed-batch experiments were conducted as follows: after a batch on a C-source at a final concentration of $40 \mathrm{~g} \mathrm{~L}^{-1}$, either a dynamic or an exponential fed-batch was performed, where the feeding rate based on $\mathrm{q}_{\mathrm{s}}$ was constantly adjusted according to the total amount of biomass in the bioreactor and controlled by the PIMS. Real-time measurement of total biomass was done by a soft-sensor tool as we described previously [17]. Off-line measurements of biomass were done every $2 \mathrm{~h}$ to correct for potential soft sensor errors. Dynamic feeding was controlled by a built-in online calculator [18] according to Eq. 1:

$$
\mathrm{F}=\frac{\mathrm{q}_{\mathrm{s}} \text { theoretical } \times \mathrm{X} \times \rho \text { feed } \times \text { reactor weight }}{\mathrm{S} \times \rho \text { broth }}
$$

$\mathrm{q}_{\mathrm{s}}$ theoretical $=\mathrm{q}_{\mathrm{s}}$ set point $\left(\mathrm{g} \mathrm{g}^{-1} \mathrm{~h}^{-1}\right) ; \mathrm{X}=$ biomass estimated by soft sensor $\left(\mathrm{g} \mathrm{L}^{-1}\right)$; $\rho$ feed $=$ density of feed $\left(\mathrm{g} \mathrm{L}^{-1}\right)$; reactor weight $(\mathrm{g}) ; \mathrm{S}=$ feed concentration $\left(\mathrm{g} \mathrm{L}^{-1}\right) ; \rho$ broth $=$ density of culture broth $\left(\mathrm{g} \mathrm{L}^{-1}\right)$.

The different fed-batch experiments, the respective feeding rates as well as the respective goals of each experiment are summarized in Table 1.

\section{Offline sample analysis}

\section{Analysis of growth and expression parameters}

Dry cell weight (DCW) was determined by centrifugation of $5 \mathrm{~mL}$ culture broth $\left(5,000 \mathrm{rpm}, 4^{\circ} \mathrm{C}, 10 \mathrm{~min}\right)$ in a laboratory centrifuge (Sigma $4 \mathrm{~K} 15$, rotor 11,156 ), washing the pellet with $5 \mathrm{~mL}$ deionized water and subsequent drying at $105^{\circ} \mathrm{C}$ to a constant weight in an oven. Optical density at $600 \mathrm{~nm}\left(\mathrm{OD}_{600}\right)$ was measured in a photometer (U-1100 Hitachi, Japan). A linear correlation between $\mathrm{DCW}$ and $\mathrm{OD}_{600}$ was experimentally determined (Eq. 2).

$$
\begin{aligned}
\mathrm{DCW}\left(\mathrm{g} \mathrm{L}^{-1}\right)= & \left(0.506 \times \mathrm{OD}_{600}+0.0006\right) \\
& \times \text { dilution factor }
\end{aligned}
$$

\begin{tabular}{|c|c|c|c|}
\hline Experiment & Substrate & Feeding strategy based on $q_{s}\left(g^{-1} h^{-1}\right)$ & Goals \\
\hline FB1 & Glycerol & $\begin{array}{l}\text { Batch on glycerol-step-wise decrease of } \mathrm{q}_{\text {s glycerol: }} \text { 0.338-0.063- } \\
\quad 0.054-0.029-0.014-0.005 \mathrm{~g} \mathrm{~g}^{-1} \mathrm{~h}^{-1}\end{array}$ & $\begin{array}{l}\text { Determination of strain physiological parameters } \\
\text { Characterization of recombinant expression profile }\end{array}$ \\
\hline FB2 & Glycerol & $\begin{array}{l}\text { Batch on glycerol-repression phase on glycerol } \\
\qquad\left(q_{s}=0.29 \mathrm{~g} \mathrm{~g}^{-1} \mathrm{~h}^{-1}\right) \text {-de-repression phase on glycerol } \\
\left(q_{\mathrm{s}}=0.035 \mathrm{~g} \mathrm{~g}^{-1} \mathrm{~h}^{-1}\right)\end{array}$ & $\begin{array}{l}\text { Mimic optimized industrial process comprising of three } \\
\text { phases }\end{array}$ \\
\hline \multirow[t]{2}{*}{ FB3 } & \multirow[t]{2}{*}{ Sorbitol } & $\begin{array}{l}\text { Batch on sorbitol-step-wise increase of } \mathrm{q}_{s} \text { sorbitol: } \\
0.033-0.060-0.127-0.176-0.197 \mathrm{~g} \mathrm{~g}^{-1} \mathrm{~h}^{-1}\end{array}$ & $\begin{array}{l}\text { Determination of strain physiological parameters } \\
\text { Characterization of recombinant expression profile }\end{array}$ \\
\hline & & $\begin{array}{l}\text { Glycerol pulse at a final concentration of } 10 \mathrm{~g} \mathrm{~L}^{-1} \\
\text { at highest } \mathrm{q}_{\mathrm{s} \text { sorbitol }}\end{array}$ & $\mathrm{q}_{\mathrm{s}}$ in presence of both substrates \\
\hline FB4 & Mixed feed & $\begin{array}{l}\text { Batch on glycerol-repression phase on glycerol } \\
\left(\mathrm{q}_{\mathrm{s}}=0.33 \mathrm{~g} \mathrm{~g}^{-1} \mathrm{~h}^{-1}\right) \text {-de-repression phase on glyc- } \\
\text { erol }\left(\mathrm{q}_{\mathrm{s}}=0.054 \mathrm{~g} \mathrm{~g}^{-1} \mathrm{~h}^{-1}\right) \text {-mixed-feed: glycerol } \\
\left(\mathrm{q}_{\mathrm{s}}=0.054 \mathrm{~g} \mathrm{~g}^{-1} \mathrm{~h}^{-1}\right) \text { and sorbitol }\left(\mathrm{q}_{\mathrm{s}}=0.070 \mathrm{~g} \mathrm{~g}^{-1} \mathrm{~h}^{-1}\right)- \\
\text { mixed-feed: } \mathrm{glycerol}\left(\mathrm{q}_{\mathrm{s}}=0.026 \mathrm{~g} \mathrm{~g}^{-1} \mathrm{~h}^{-1}\right) \text { and sorbitol } \\
\left(\mathrm{q}_{\mathrm{s}}=0.015 \mathrm{~g} \mathrm{~g}^{-1} \mathrm{~h}^{-1}\right)\end{array}$ & $\begin{array}{l}\text { Analyze physiology and productivity in mixed feed } \\
\text { environment }\end{array}$ \\
\hline FB5 & Mixed feed & $\begin{array}{l}\text { batch on glycerol- repression phase on glyc- } \\
\text { erol }\left(\mathrm{q}_{\mathrm{s}}=0.33 \mathrm{~g}^{-1} \mathrm{~h}^{-1}\right) \text {-mixed-feed: glycerol } \\
\quad\left(\mathrm{q}_{\mathrm{s}}=0.040 \mathrm{~g}^{-1} \mathrm{~h}^{-1}\right) \text { and sorbitol }\left(\mathrm{q}_{\mathrm{s}}=0.055 \mathrm{~g} \mathrm{~g}^{-1} \mathrm{~h}^{-1}\right)\end{array}$ & Verify increased STY in mixed feed environment \\
\hline FB6 & Mixed feed & $\begin{array}{l}\text { batch on glycerol-repression phase on glycerol } \\
\left(\mathrm{q}_{\mathrm{s}}=0.23 \mathrm{~g} \mathrm{~g}^{-1} \mathrm{~h}^{-1}\right) \text {-mixed-feed: glycerol } \\
\left(\mathrm{q}_{\mathrm{s}}=0.026 \mathrm{~g} \mathrm{~g}^{-1} \mathrm{~h}^{-1}\right) \text { and sorbitol }\left(\mathrm{q}_{\mathrm{s}}=0.027 \mathrm{~g} \mathrm{~g}^{-1} \mathrm{~h}^{-1}\right)- \\
\text { mixed-feed: } \mathrm{glycerol}\left(\mathrm{q}_{\mathrm{s}}=0.026 \mathrm{~g} \mathrm{~g}^{-1} \mathrm{~h}^{-1}\right) \text { and sorbitol } \\
\left(\mathrm{q}_{\mathrm{s}}=0.061 \mathrm{~g} \mathrm{~g}^{-1} \mathrm{~h}^{-1}\right)\end{array}$ & $\begin{array}{l}\text { Verify increased STY in mixed feed environment } \\
\text { Identification of } q_{s} \text { glycerol } / q_{s} \text { sorbitol ratio allowing highest } \\
\text { productivity and STY }\end{array}$ \\
\hline
\end{tabular}

Table 1 Overview of dynamic fed-batch experiments 
Since the regression coefficient $\mathrm{R}^{2}$ was 0.996 , Eq. 2 was used for regular $\mathrm{q}_{\mathrm{s}}$ adjustments of the feed based on $\mathrm{OD}_{600}$ measurements.

\section{Substrates and metabolites}

Concentrations of carbon sources and metabolites were determined in cell free cultivation broth using HPLC (Agilent Technologies, USA), equipped with a Supelcoguard column, a Supelcogel C-610 $\mathrm{H}$ ion exchange column (Sigma-Aldrich, USA) and a refractive index detector (Agilent Technologies, USA). The mobile phase was $0.1 \% \mathrm{H}_{3} \mathrm{PO}_{4}$ with a constant flow rate of $0.5 \mathrm{~mL} \mathrm{~min}^{-1}$ and the system was run isocratically at $30^{\circ} \mathrm{C}$. All measurements were executed in duplicates.

\section{PLC activity assay}

Recombinant PLC activity in cell-free cultivation broth was determined with a colorimetric method based on the hydrolysis of $p$-nitrophenylphosphorylcholine ( $p$-NPPC) [19]. Quantification was done with a photometer (U-1100 Hitachi, Japan). The standard curve was prepared with commercial PLC from B. cereus (Sigma-Aldrich, P6621250UN) dissolved in HEPES buffer (50 mM, pH 7.0) and $p$-NPPC (Melford, 21064-69-7) substrate solution (100 mM in $250 \mathrm{mM}$ HEPES buffer, $0.1 \mathrm{mM} \mathrm{ZnCl}, \mathrm{pH}$ 7.0, $30 \%$ sorbitol). $540 \mu \mathrm{L}$ of cell-free cultivation broth were mixed with $60 \mu \mathrm{L}$ of $p$-NPPC substrate solution. The mixture was incubated at $37^{\circ} \mathrm{C}$ for $60 \mathrm{~min}$ [20] and enzymatic activity was followed at $410 \mathrm{~nm}$ [21]. Total extracellular protein content was determined by the Bradford Reagent (Sigma-Aldrich, B6919) at $595 \mathrm{~nm}$.

\section{Results and discussion}

\section{Dynamic batch cultivation with substrate pulses}

To identify a second C-source for developing the mixedfeed strategy for the recombinant $P$. pastoris de-repression strain, we performed a dynamic batch cultivation with substrate pulses. After a batch on glucose, the C-sources glucose, sorbitol, mannose, fructose, maltose, glycerol and lactic acid were sequentially pulsed twice to the culture each in a final concentration of $45 \mathrm{mM}$. In Figure 1 the carbon dioxide evolution rate (CER), depicting metabolic activity, and the calculated specific substrate uptake rates $\left(\mathrm{q}_{\mathrm{s}}\right)$ are shown.

Based on offline analysis, specific rates and yields were calculated. We also analyzed productivity, formation of metabolites as well as economic aspects. As shown in Table 2, all substrates were taken up; however, maltose and lactic acid were only metabolized at low rates. Metabolism of glucose and mannose led to the formation of ethanol, which could be problematic in mixed feed experiments. We analyzed the volumetric productivity $\left(r_{p}\right)$ for each substrate pulse and found promoter de-repression in each phase. However, fructose and lactic

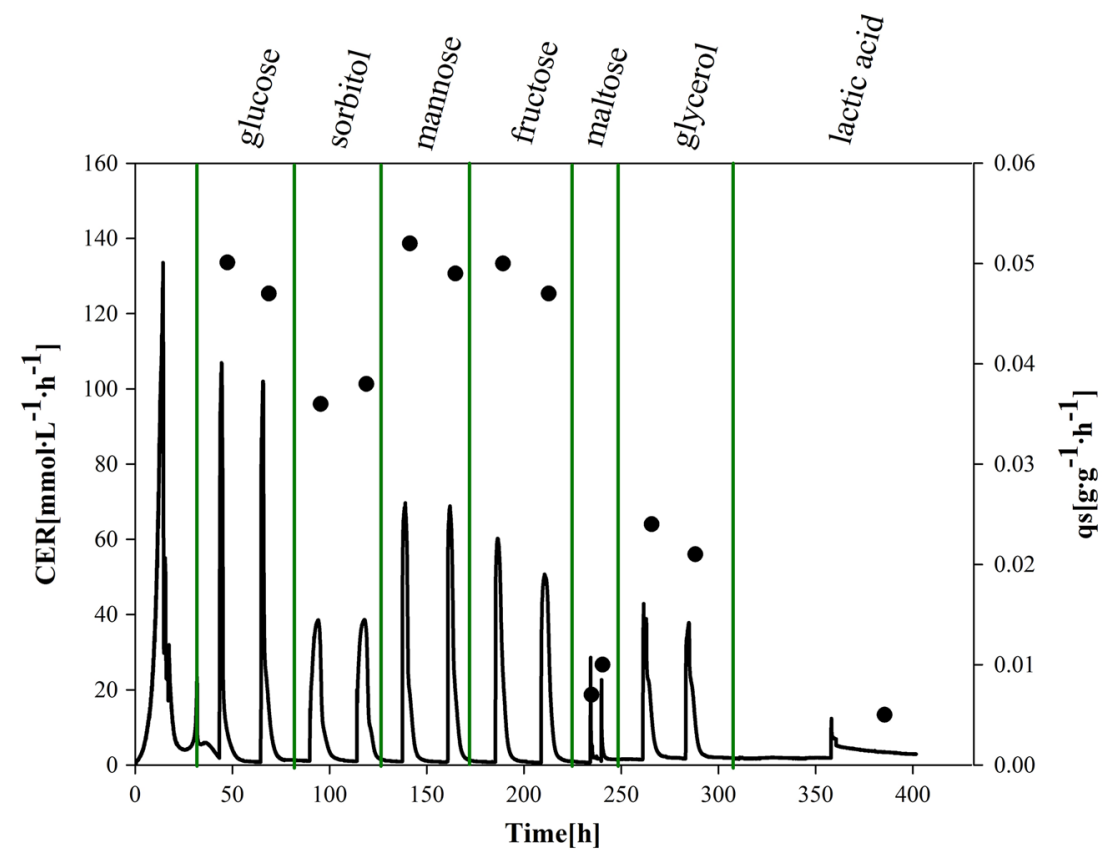

Figure 1 Dynamic batch cultivation with substrate pulses. Glucose, sorbitol, mannose, fructose, maltose, glycerol and lactic acid were sequentially pulsed after a batch on glucose. The CER signal (continuous black line) was used to follow metabolic activity. The specific substrate uptake rate ( $\mathrm{q}_{\mathrm{s}}$ black dot) was determined for the different substrates. 
Table 2 Summary of strain specific parameters, metabolites and STY during dynamic batch experiment with substrate pulses as well as economic aspects

\begin{tabular}{|c|c|c|c|c|c|c|c|}
\hline C-source & $q_{s}\left(g^{-1} h^{-1}\right)$ & $\mathrm{Y}_{\mathrm{CO}_{2} / \mathrm{S}}\left(\mathrm{mol} \mathrm{Cmol}^{-1}\right)$ & $\mathrm{Y}_{\mathrm{X} / \mathrm{S}}\left(\mathrm{Cmol} \mathrm{Cmol}^{-1}\right)$ & C-balance & Metabolites & $\begin{array}{l}r_{p}\left(U L^{-1} h^{-1}\right) \\
\text { per pulse }\end{array}$ & Price $\left(€ \mathbf{k g}^{-1}\right)$ \\
\hline Glucose (batch) & 0.059 & 0.53 & 0.498 & 1.03 & $\begin{array}{l}\text { Acetate }\left(3.0 \mathrm{~g} \mathrm{~L}^{-1}\right) \\
\text { Ethanol }\left(0.6 \mathrm{~g} \mathrm{~L}^{-1}\right)\end{array}$ & 6.2 & \\
\hline Glucose & 0.048 & 0.93 & 0.004 & 0.94 & Ethanol $\left(0.3 \mathrm{~g} \mathrm{~L}^{-1}\right)$ & 4.2 & 40 \\
\hline Sorbitol & 0.037 & 0.94 & 0.002 & 0.94 & nd & 4.8 & 20 \\
\hline Mannose & 0.051 & 0.93 & 0.008 & 0.94 & ethanol $\left(1.0 \mathrm{~g} \mathrm{~L}^{-1}\right)$ & 4.7 & 2,000 \\
\hline Fructose & 0.048 & 0.90 & 0.036 & 0.94 & nd & 2.2 & 62 \\
\hline Maltose & 0.006 & 0.93 & 0.014 & 0.94 & nd & 5.4 & 252 \\
\hline Glycerol & 0.023 & 1.04 & 0.011 & 1.05 & nd & 4.3 & 26 \\
\hline Lactic acid & 0.005 & 1.04 & 0.000 & 1.04 & nd & 0.5 & 24 \\
\hline
\end{tabular}

$q_{s}$ specific substrate uptake rate, $\mathrm{Y}_{\mathrm{CO}_{2} / \mathrm{s}}$ and $\mathrm{Y}_{\mathrm{X} / \mathrm{S}}$ yields of $\mathrm{CO}_{2}$ and biomass, $\mathrm{C}$-balance sum of $\mathrm{Y}_{\mathrm{CO}_{2} / \mathrm{s} a n d} \mathrm{Y}_{\mathrm{X} / \mathrm{s}}$ which should ideally give 1.0 , $r_{p}$ volumetric productivity per pulse and $n d$ none determined.

acid gave lower $r_{p}$ compared to the other substrates. Closing C-balances confirmed data validity (Table 2). Taken together, based on physiology, productivity and economic aspects we chose sorbitol as 2nd C-source for the development of a mixed feed strategy.

\section{Fed-batch cultivations}

\section{Dynamic fed-batch on glycerol as sole carbon-source (FB1)}

In order to physiologically characterize the recombinant P. pastoris de-repression strain and identify the glycerol concentration allowing for full promoter de-repression, we performed FB1 where we stepwise adapted the feeding rate to correspond to lower $\mathrm{q}_{\mathrm{s} \text { glycerol }}$ (Table 1; Additional file 1: Figure S1).

As expected, decreasing $\mathrm{q}_{\mathrm{s}}$. glycerol resulted in a decreased specific growth rate $(\mu)$ and a decreased $Y_{X / S}$ (Table 3). In particular, by adjusting the feeding rate to correspond to a $\mathrm{q}_{\mathrm{s} \text { glycerol }}$ between $0.029 \mathrm{~g} \mathrm{~g}^{-1} \mathrm{~h}^{-1}$ and $0.054 \mathrm{~g} \mathrm{~g}^{-1} \mathrm{~h}^{-1}$ we could nicely determine the maintenance level of this yeast strain (Additional file 2: Figure S2). At $\mathrm{q}_{\mathrm{s} \text { glycerol }}$ lower than $0.05 \mathrm{~g} \mathrm{~g}^{-1} \mathrm{~h}^{-1}$, the cells use the $\mathrm{C}$-source for maintenance metabolism and not for growth, which is shown in increasing $\mathrm{Y}_{\mathrm{CO}_{2} / \mathrm{S}}$ values. Only at $\mathrm{q}_{\mathrm{s} \text { glycerol }}$ higher than $0.05 \mathrm{~g} \mathrm{~g}^{-1} \mathrm{~h}^{-1}$, the cells can efficiently produce biomass and product.
When we analyzed $r_{p}$ and $q_{p}$ during the single $\mathrm{q}_{\mathrm{s} \text { glycerol }}$ steps, we determined apparent full promoter de-repression at a $\mathrm{q}_{\text {s glycerol }}=0.054 \mathrm{~g} \mathrm{~g}^{-1} \mathrm{~h}^{-1}$ (Table 3). Interestingly, by further lowering $\mathrm{q}_{\mathrm{s}}$ glycerol, also productivity decreased. Apparently, maximum productivity for the recombinant $P$. pastoris de-repression strain is directly linked to an optimum $\mathrm{q}_{\mathrm{s} \text { glycerol. }}$ As soon as the cells come close to their maintenance level, $r_{p}$ and $q_{p}$ decrease dramatically, leaving only a narrow operating window for the design of an efficient de-repression fed-batch (Additional file 3: Figure S3, Additional file 4: Figure S4).

Production fed-batch on glycerol as sole carbon-source (FB2) Based on data from FB1, we performed FB2 to mimic an optimized industrial process comprising of the three phases (1) batch on glycerol, (2) repressed fed-batch at high $\mathrm{q}_{\mathrm{s} \text { glycerol }}$ and (3) de-repressed fed-batch at low $\mathrm{q}_{\mathrm{s} \text { glycerol }}$ (Table 1). After the batch, we cultivated the cells at a repressing $\mathrm{q}_{\mathrm{s} \text { glycerol }}=0.29 \mathrm{~g} \mathrm{~g}^{-1} \mathrm{~h}^{-1}$ to a biomass concentration of $60 \mathrm{~g} \mathrm{~L}^{-1}$. Then we adjusted the feeding rate to correspond to a de-repressing $\mathrm{q}_{\mathrm{s} \text { glycerol }}=0.035 \mathrm{~g} \mathrm{~g}^{-1} \mathrm{~h}^{-1}$ and continued the cultivation for another $24 \mathrm{~h}$. The final biomass concentration was $65 \mathrm{~g} \mathrm{~L}^{-1}$. In Table 4 the physiological strain characteristic parameters are summarized. In

Table 3 Strain characteristic parameters during the dynamic fed-batch on glycerol (FB1)

\begin{tabular}{|c|c|c|c|c|c|c|}
\hline$q_{\text {s glycerol }}\left(\mathrm{g} \mathrm{g}^{-1} h^{-1}\right)$ & $\mu\left(h^{-1}\right)$ & $\mathrm{Y}_{\mathrm{CO}_{2} / \mathrm{S}}\left(\mathrm{mol} \mathrm{Cmol}^{-1}\right)$ & $\mathrm{Y}_{\mathrm{X} / \mathrm{s}}\left(\mathrm{Cmol} \mathrm{Cmol}^{-1}\right)$ & C-balance & $r_{p}\left(U L^{-1} h^{-1}\right)$ & $q_{p}\left(U g^{-1} h^{-1}\right)$ \\
\hline 0.338 & 0.199 & 0.29 & 0.70 & 0.99 & 2.45 & 0.03 \\
\hline 0.063 & 0.026 & 0.52 & 0.47 & 0.99 & 5.38 & 0.06 \\
\hline 0.054 & 0.024 & 0.43 & 0.53 & 0.96 & 54.8 & 0.57 \\
\hline 0.029 & 0.008 & 0.61 & 0.34 & 0.95 & 13.8 & 0.14 \\
\hline 0.014 & 0.000 & 0.91 & 0.03 & 0.94 & 13.5 & 0.13 \\
\hline 0.005 & 0.000 & 1.01 & 0.01 & 1.02 & 6.08 & 0.06 \\
\hline
\end{tabular}


Table 4 Strain characteristic parameters during the production fed-batch on glycerol (FB2)

\begin{tabular}{|c|c|c|c|c|c|c|}
\hline$q_{s \text { glycerol }}\left(g_{\left.g^{-1} h^{-1}\right)}\right.$ & $\mu\left(h^{-1}\right)$ & $\mathrm{Y}_{\mathrm{CO}_{2} / \mathrm{s}}\left(\mathrm{mol} \mathrm{Cmol}^{-1}\right)$ & $\mathrm{Y}_{\mathrm{X} / \mathrm{s}}\left(\mathrm{Cmol} \mathrm{Cmol}^{-1}\right)$ & C-balance & $r_{p}\left(U L^{-1} h^{-1}\right)$ & $q_{p}\left(U g^{-1} h^{-1}\right)$ \\
\hline 0.29 & 0.104 & 0.40 & 0.58 & 0.98 & 0 & 0 \\
\hline 0.035 & 0.012 & 0.73 & 0.30 & 1.03 & 23.6 & 0.36 \\
\hline
\end{tabular}

the de-repressed phase we determined $r_{\mathrm{p}}=23.6 \mathrm{U} \mathrm{L}^{-1} \mathrm{~h}^{-1}$ and $\mathrm{q}_{\mathrm{p}}=0.36 \mathrm{U} \mathrm{g}^{-1} \mathrm{~h}^{-1}$.

\section{Dynamic fed-batch on sorbitol as sole carbon-source (FB3)}

To characterize the recombinant $P$. pastoris de-repression strain on sorbitol, we performed a batch on sorbitol which was followed by a fed-batch where we stepwise increased $\mathrm{q}_{\mathrm{s} \text { sorbitol }}$ (Table 1; Additional file 5: Figure S5).

We observed an extremely long lag phase during the batch at a concentration of $40 \mathrm{~g} \mathrm{~L}^{-1}$ sorbitol (Additional file 5: Figure S5). We speculate that an osmotic shock caused by the high sorbitol concentration could have caused this long lag phase [22, 23]. However, when we analyzed the different $\mathrm{q}_{\mathrm{s} \text { sorbitol }}$ steps, we observed a nice correlation between $\mathrm{q}_{\mathrm{s} \text { sorbitol }}, \mu$ and $\mathrm{Y}_{\mathrm{X} / \mathrm{S}}$ (Table 5) and thus were again able to determine the maintenance level of the strain between $\mathrm{q}_{\mathrm{s} \text { sorbitol }}=0.060$ and $0.127 \mathrm{~g} \mathrm{~g}^{-1} \mathrm{~h}^{-1}$ (Additional file 6: Figure S6).

When we raised $\mathrm{q}_{\text {s sorbitol }}>0.197 \mathrm{~g} \mathrm{~g}^{-1} \mathrm{~h}^{-1}$, we observed sorbitol accumulation. Interestingly, productivity increased concomitantly with $\mathrm{q}_{\mathrm{s}}$ sorbitol and the substrate did not repress the promoter at any concentration (Table 5; Additional file 7: Figure S7, Additional file 8: Figure S8). At the end of cultivation we determined a biomass concentration of around $40 \mathrm{~g} \mathrm{~L}^{-1}$.

To analyze if sorbitol and glycerol can be taken up concomitantly and identify the respective $\mathrm{q}_{\mathrm{s}}$ values, we pulsed glycerol at a final concentration of $10 \mathrm{~g} \mathrm{~L}^{-1}$ to the culture while sorbitol was fed at a constant $\mathrm{q}_{\mathrm{s} \text { sorbitol }}=$ $0.197 \mathrm{~g} \mathrm{~g}^{-1} \mathrm{~h}^{-1}$. The cells immediately reacted to glycerol, as indicated by a sudden increase in the CER (Figure 2).

Sampling before and after the glycerol pulse and offline analysis allowed the determination of physiological parameters. As shown in Table 6, glycerol was specifically taken up at a rather high rate of $0.193 \mathrm{~g} \mathrm{~g}^{-1} \mathrm{~h}^{-1}$, whereas $\mathrm{q}_{\mathrm{s} \text { sorbitol }}$ decreased from 0.197 to $0.071 \mathrm{~g} \mathrm{~g}^{-1} \mathrm{~h}^{-1}$.
Although the recombinant $P$. pastoris de-repression strain preferred glycerol as substrate, both C-sources were taken up concomitantly. This was a crucial observation, as the concomitant uptake was an essential requirement for the development of a mixed feed strategy. As expected, we did not determine an increase of the total amount of PLC in the cultivation broth after pulsing glycerol in a repressing concentration. However, we even determined a lower total amount of active PLC in the cultivation broth after the pulse, indicating PLC to be a very unstable product, which constantly degraded and/or lost activity in the bioreactor.

\section{Dynamic mixed feed fed-batch (FB4)}

In order to verify $\mathrm{q}_{\mathrm{s}}$ for both glycerol and sorbitol, we performed a dynamic mixed feed fed-batch. After a fed-batch phase on glycerol at a repressing concentration of $\mathrm{q}_{\text {s glycerol }}=0.33 \mathrm{~g} \mathrm{~g}^{-1} \mathrm{~h}^{-1}$ to a biomass concentration of around $40 \mathrm{~g} \mathrm{~L}^{-1}$, we de-repressed the promoter at a $\mathrm{q}_{\mathrm{s} \text { glycerol }}=0.054 \mathrm{~g} \mathrm{~g}^{-1} \mathrm{~h}^{-1}$ for $24 \mathrm{~h}$ to get a biomass concentration of around $60 \mathrm{~g} \mathrm{~L}^{-1}$. Then we added the 2 nd $\mathrm{C}$-source sorbitol and performed two different mixed feed phases: first we concomitantly fed glycerol at $\mathrm{q}_{\mathrm{s} \text { glycerol }}=0.054 \mathrm{~g} \mathrm{~g}^{-1} \mathrm{~h}^{-1}$ and sorbitol at $\mathrm{q}_{\mathrm{s} \text { sorbitol }}=0.070 \mathrm{~g} \mathrm{~g}^{-1} \mathrm{~h}^{-1}$ for $8 \mathrm{~h}$ giving a biomass concentration of $78 \mathrm{~g} \mathrm{~L}^{-1}$, before we adapted the feeding rates to correspond to a $\mathrm{q}_{\mathrm{s} \text { glycerol }}=0.026 \mathrm{~g} \mathrm{~g}^{-1} \mathrm{~h}^{-1}$ and $\mathrm{q}_{\mathrm{s} \text { sorbitol }}=0.015 \mathrm{~g} \mathrm{~g}^{-1} \mathrm{~h}^{-1}$ for another $52 \mathrm{~h}$ resulting in a biomass concentration of around $66 \mathrm{~g} \mathrm{~L}^{-1}$. The results of this dynamic experiment are summarized in Table 7.

As shown in Table 7, the concomitant presence of sorbitol boosted $\mu$ more than 4-fold from 0.018 to $0.082 \mathrm{~h}^{-1}$. We could also follow the positive effect of sorbitol on cell growth by shifts in both yields. When we reduced $\mathrm{q}_{\mathrm{s}}$ for both substrates in the later phase of the mixed feed

Table 5 Strain characteristic parameters during the dynamic fed-batch on sorbitol (FB3)

\begin{tabular}{|c|c|c|c|c|c|c|}
\hline$q_{s \text { sorbitol }}\left(g g^{-1} h^{-1}\right)$ & $\mu\left(h^{-1}\right)$ & $\mathrm{Y}_{\mathrm{CO}_{2} / \mathrm{s}}\left(\mathrm{mol} \mathrm{Cmol}^{-1}\right)$ & $\mathrm{Y}_{\mathrm{x} / \mathrm{s}}\left(\mathrm{Cmol} \mathrm{Cmol}^{-1}\right)$ & C-balance & $r_{p}\left(U L^{-1} h^{-1}\right)$ & $q_{p}\left(U g^{-1} h^{-1}\right)$ \\
\hline 0.033 & 0.005 & 0.76 & 0.16 & 0.92 & 0.63 & 0.028 \\
\hline 0.060 & 0.018 & 0.57 & 0.36 & 0.93 & 1.37 & 0.032 \\
\hline 0.127 & 0.059 & 0.47 & 0.55 & 1.02 & 4.74 & 0.051 \\
\hline 0.176 & 0.084 & 0.45 & 0.56 & 1.01 & 10.4 & 0.170 \\
\hline 0.197 & 0.088 & 0.48 & 0.53 & 1.01 & 33.0 & 0.951 \\
\hline
\end{tabular}




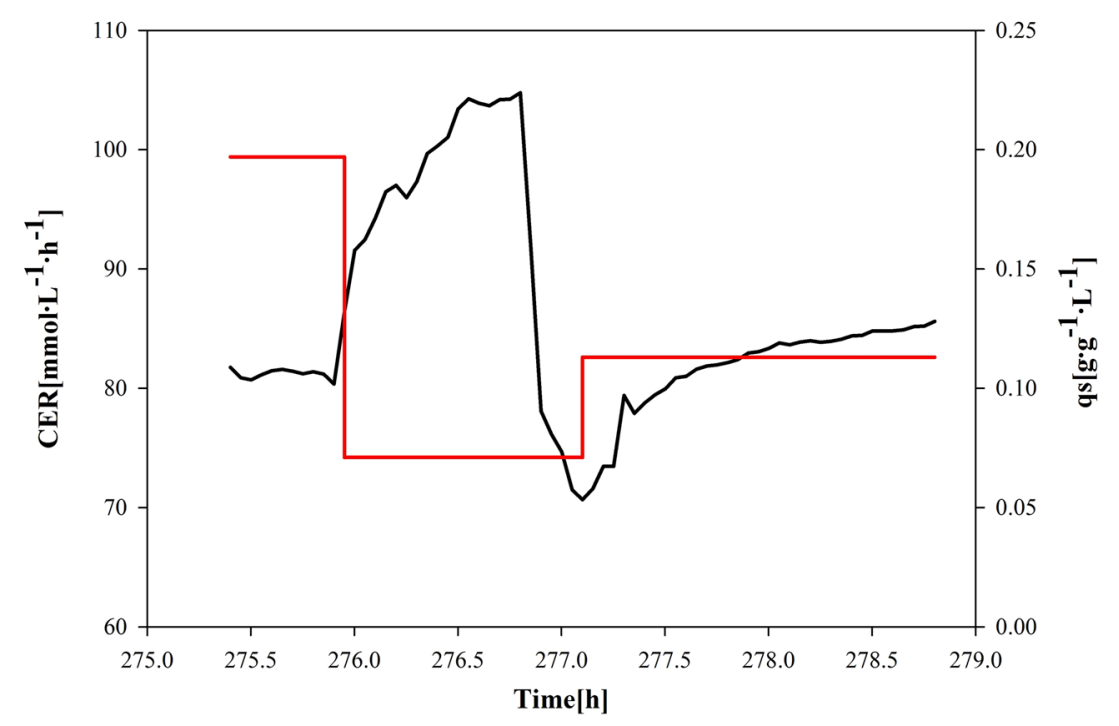

Figure 2 Glycerol pulse during sorbitol fed-batch. Carbon dioxide evolution rate (CER, continuous black line) and specific sorbitol uptake rate $\left(\mathrm{q}_{\mathrm{s} \text { sorbitol, }}\right.$ continuous red line). After glycerol pulse a sudden increase in the CER signal and a concomitant decrease in $\mathrm{q}_{\mathrm{s}}$ sorbitol were observed.

Table 6 Strain characteristic parameters during a glycerol pulse in sorbitol fed-batch FB3 (glycerol was pulsed at a final concentration of $10 \mathrm{~g} \mathrm{~L}^{-1}$ to the culture while sorbitol was fed at a constant $q_{\text {s sorbitol }}=0.197 \mathrm{~g} \mathrm{~g}^{-1} \mathrm{~h}^{-1}$ )

\begin{tabular}{|c|c|c|c|c|c|c|c|}
\hline$q_{s}$ glycerol $\left(g^{-1} h^{-1}\right)$ & $q_{s \text { sorbitol }}\left(g_{g^{-1}} h^{-1}\right)$ & $\mu\left(h^{-1}\right)$ & $\mathrm{Y}_{\mathrm{CO}_{2} / \mathrm{s}}\left(\mathrm{mol} \mathrm{Cmol}^{-1}\right)$ & $\mathrm{Y}_{\mathrm{X} / \mathrm{s}}\left(\mathrm{Cmol} \mathrm{Cmol}^{-1}\right)$ & C-balance & $r_{p}\left(U L^{-1} h^{-1}\right)$ & $q_{p}\left(U g^{-1} h^{-1}\right)$ \\
\hline 0.193 & 0.071 & 0.186 & 0.26 & 0.71 & 0.97 & $0^{*}$ & $0^{*}$ \\
\hline
\end{tabular}

* We even measured less active PLC after the glycerol pulse than before, indicating product instability.

Table 7 Strain characteristic parameters during dynamic mixed feed fed-batch FB4

\begin{tabular}{|c|c|c|c|c|c|c|c|}
\hline$q_{\text {s glycerol }}\left(\mathrm{g} \mathrm{g}^{-1} h^{-1}\right)$ & $q_{s \text { sorbitol }}\left(g g^{-1} h^{-1}\right)$ & $\mu\left(h^{-1}\right)$ & $\mathrm{Y}_{\mathrm{CO}_{2} / \mathrm{S}}\left(\mathrm{mol} \mathrm{Cmol}^{-1}\right)$ & $\mathrm{Y}_{\mathrm{X} / \mathrm{S}}\left(\mathrm{Cmol} \mathrm{Cmol}^{-1}\right)$ & C-balance & $r_{p}\left(U L^{-1} h^{-1}\right)$ & $q_{p}\left(U g^{-1} h^{-1}\right)$ \\
\hline 0.33 & - & 0.174 & 0.38 & 0.63 & 1.01 & 0 & 0 \\
\hline 0.054 & - & 0.018 & 0.63 & 0.42 & 1.05 & 5.24 & 0.080 \\
\hline 0.054 & 0.070 & 0.082 & 0.44 & 0.57 & 1.01 & 13.25 & 0.143 \\
\hline 0.026 & 0.015 & 0.011 & 0.80 & 0.20 & 1.00 & 5.57 & 0.099 \\
\hline
\end{tabular}

fed-batch, also $\mu$ dramatically decreased. In terms of productivity, we obtained a 2 -fold increase in the first mixed feed phase compared to the glycerol de-repression phase. When we decreased both $\mathrm{q}_{\mathrm{s}}$ values, also productivities decreased. Interestingly, for the de-repression phase at $\mathrm{q}_{\mathrm{s} \text { glycerol }}=0.054 \mathrm{~g} \mathrm{~g}^{-1} \mathrm{~h}^{-1}$ we only obtained $\mathrm{r}_{\mathrm{p}}=5.24 \mathrm{U} \mathrm{L}^{-1} \mathrm{~h}^{-1}$ and $\mathrm{q}_{\mathrm{p}}=0.08 \mathrm{U} \mathrm{g}^{-1} \mathrm{~h}^{-1}$ which was 4-fold lower compared to the results obtained in FB2 at $\mathrm{q}_{\mathrm{s} \text { glycerol }}=0.035 \mathrm{~g} \mathrm{~g}^{-1} \mathrm{~h}^{-1}$. Based on our observations in FB1, we actually expected an even higher productivity at $\mathrm{q}_{\mathrm{s} \text { glycerol }}=0.054 \mathrm{~g} \mathrm{~g}^{-1} \mathrm{~h}^{-1}$. We currently have no explanation for this mismatch, however we speculate that a different batch of p-NPPC substrate might have caused this aberration. Thus, for the following experiments we always used the same batch of substrate. However, for FB4 a direct comparison between the different phases was still possible and legitimate, showing a beneficial effect of a mixed feed environment on productivity compared to a single substrate de-repression strategy.

\section{Production mixed feed fed-batch (FB5)}

In order to verify the higher productivity observed for a mixed feed environment compared to a de-repression strategy on glycerol as sole C-source, we performed FB5. First we performed a de-repressed fed-batch phase at a $\mathrm{q}_{\mathrm{s} \text { glycerol }}=0.33 \mathrm{~g} \mathrm{~g}^{-1} \mathrm{~h}^{-1}$ to a biomass concentration of 
Table 8 Strain characteristic parameters during production mixed feed fed-batch FB5

\begin{tabular}{|c|c|c|c|c|c|c|c|}
\hline$q_{s \text { glycerol }}\left(\mathrm{g} \mathrm{g}^{-1} \mathrm{~h}^{-1}\right)$ & $q_{\text {s sorbitol }}\left(g^{-1} h^{-1}\right)$ & $\mu\left(h^{-1}\right)$ & $\mathrm{Y}_{\mathrm{CO}_{2} / \mathrm{S}}\left(\mathrm{mol} \mathrm{Cmol}^{-1}\right)$ & $\mathrm{Y}_{\mathrm{X} / \mathrm{S}}\left(\mathrm{Cmol} \mathrm{Cmol}^{-1}\right)$ & C-balance & $r_{p}\left(U L^{-1} h^{-1}\right)$ & $q_{p}\left(U g^{-1} h^{-1}\right)$ \\
\hline 0.33 & - & 0.189 & 0.32 & 0.69 & 1.01 & 0 & 0 \\
\hline 0.040 & 0.055 & 0.062 & 0.41 & 0.63 & 1.04 & 64.7 & 0.86 \\
\hline
\end{tabular}

$65 \mathrm{~g} \mathrm{~L}^{-1}$, before we started the mixed feed where we kept $\mathrm{q}_{\mathrm{s}}$ values for both substrates constant (Table 8).

Compared to the production fed-batch on glycerol as sole carbon-source (FB2), where we determined $\mu=0.012 \mathrm{~h}^{-1}, \mathrm{r}_{\mathrm{p}}=23.6 \mathrm{U} \mathrm{L}^{-1} \mathrm{~h}^{-1}$ and $\mathrm{q}_{\mathrm{p}}=0.36$ $\mathrm{U} \mathrm{g}^{-1} \mathrm{~h}^{-1}$ at a $\mathrm{q}_{\mathrm{s} \text { glycerol }}=0.035 \mathrm{~g} \mathrm{~g}^{-1} \mathrm{~h}^{-1}$ (Table 3), we increased $\mu 5$-fold to $\mu=0.062 \mathrm{~h}^{-1}, \mathrm{r}_{\mathrm{p}} 2.8$-fold to $\mathrm{r}_{\mathrm{p}}=65.7 \mathrm{U} \mathrm{L}^{-1} \mathrm{~h}^{-1}$ and $\mathrm{q}_{\mathrm{p}} 2.4$-fold to $\mathrm{q}_{\mathrm{p}}=0.86$ $\mathrm{U} \mathrm{g}^{-1} \mathrm{~h}^{-1}$ at a comparable $\mathrm{q}_{\mathrm{s} \text { glycerol in a mixed feed }}$ environment with concomitant uptake of sorbitol. This clearly shows the beneficial effect of the mixed feed system on productivity and STY compared to the single substrate strategy.

\section{Production mixed feed fed-batch (FB6)}

To determine a potential optimal ratio between $\mathrm{q}_{\mathrm{s} \text { glycerol }}$ and $\mathrm{q}_{\mathrm{s} \text { sorbitol }}$, we performed FB6, where, after a repression phase on glycerol to a biomass concentration of $60 \mathrm{~g} \mathrm{~L}^{-1}$, we tested 2 different mixed feed environments (Table 9). The productivity values determined in the first mixed feed phase were comparable to the values determined in the previous fedbatch experiments. Interestingly, by keeping $\mathrm{q}_{\mathrm{s} \text { glycerol }}$ constant and increasing $\mathrm{q}_{\mathrm{s}}$ sorbitol around 2-fold we increased $\mu$, but significantly decreased the productivity (Table 9). This was rather surprising, since we expected to further increase productivity by increasing $\mathrm{q}_{\mathrm{s} \text { sorbitol }}$ and thus $\mu$. However, the results suggest, that the boost in productivity does not result from a higher $\mu$, but rather from a certain ratio of $\mathrm{q}_{\mathrm{s} \text { glycerol }}$ to $\mathrm{q}_{\mathrm{s} \text { sorbitol}}$. Thus, we plotted the ratio $\frac{\mathrm{q}_{\mathrm{s} \text { glycerol }}}{\mathrm{q}_{\mathrm{s} \text { sorbitol }}}$ of FB3, FB5 and FB6 against productivity values (Figures 3, 4). Due to the different substrate batches for activity measurements and thus possibly non-comparable productivity values, we did not consider FB4 for this mechanistic
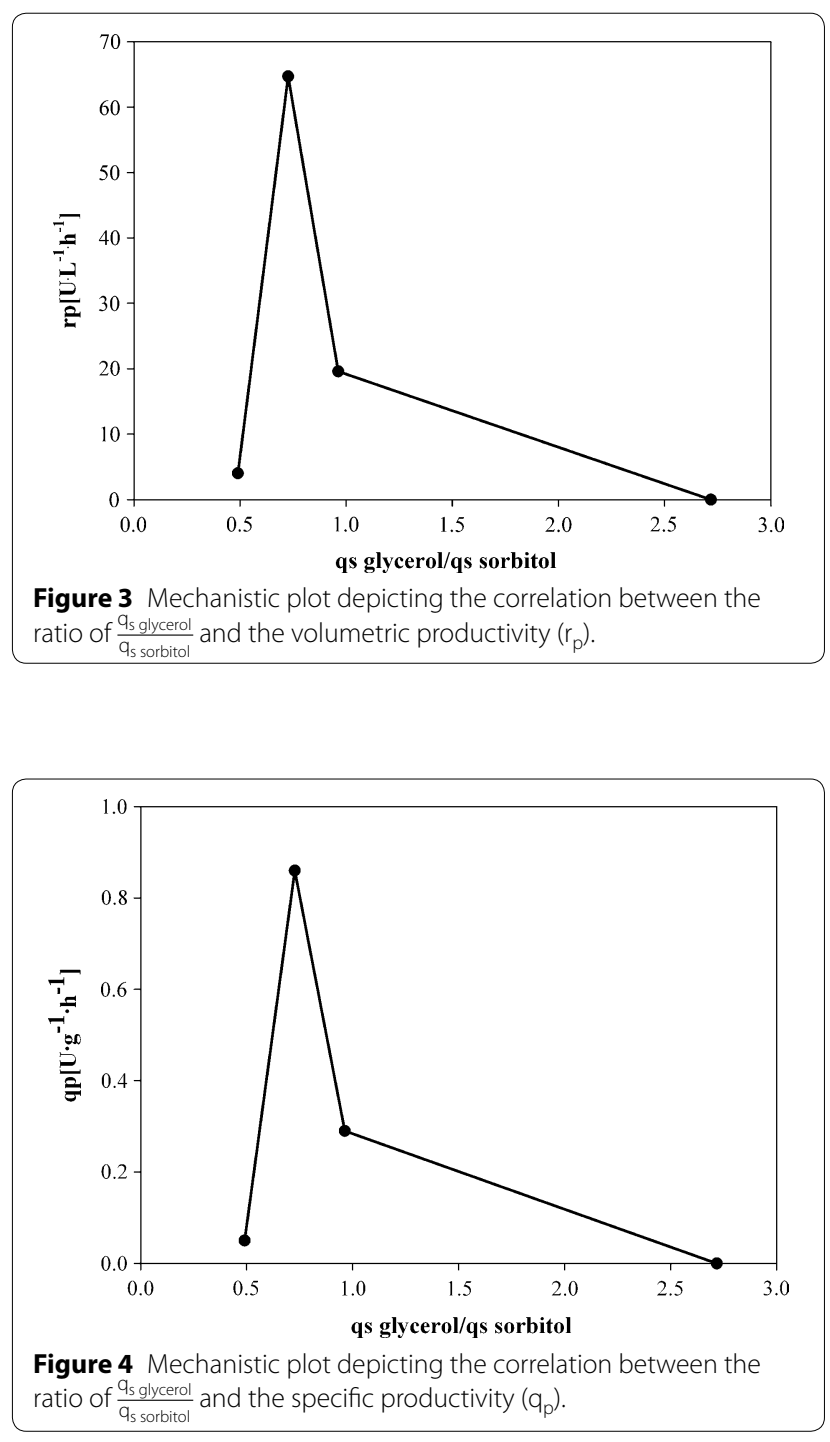

Table 9 Strain characteristic parameters during production mixed feed fed-batch FB6

\begin{tabular}{|c|c|c|c|c|c|c|c|}
\hline$q_{\text {s glycerol }}\left(g g^{-1} h^{-1}\right)$ & $q_{s \text { sorbitol }}\left(\mathbf{g ~ g}^{-1} \mathbf{h}^{-1}\right)$ & $\mu\left(h^{-1}\right)$ & $\mathrm{Y}_{\mathrm{CO}_{2} / \mathrm{S}}\left(\mathrm{mol} \mathrm{Cmol}^{-1}\right)$ & $\mathrm{Y}_{\mathrm{X} / \mathrm{s}}\left(\mathrm{Cmol} \mathrm{Cmol}^{-1}\right)$ & C-balance & $r_{p}\left(U L^{-1} h^{-1}\right)$ & $q_{p}\left(U g^{-1} h^{-1}\right)$ \\
\hline 0.23 & - & 0.127 & 0.35 & 0.67 & 1.02 & 0 & 0 \\
\hline 0.026 & 0.027 & 0.022 & 0.52 & 0.50 & 1.02 & 19.6 & 0.29 \\
\hline 0.026 & 0.061 & 0.053 & 0.30 & 0.72 & 1.02 & 4.03 & 0.05 \\
\hline
\end{tabular}


plot. As shown in Figures 3 and 4, a ratio $\frac{\mathrm{q}_{\mathrm{s} g l y c e r o l}}{\mathrm{q}_{\mathrm{s} s o r b i t o l}}$ of around 0.7 is most beneficial for productivity.

\section{Conclusions}

In this study we physiologically characterized a recombinant $P$. pastoris strain, where the gene coding for the recombinant product phospholipase C (PLC) was under the control of a mutated AOX1 promoter, which gets de-repressed at limiting concentrations of glycerol. Based on physiological data we developed a mixed feed strategy for this novel de-repression strain and compared productivity data to the commonly used single substrate strategy. Our findings can be summarized as:

- A dynamic batch with substrate pulses revealed sorbitol as second C-source for the development of a mixed feed strategy.

- The specific substrate uptake rate for glycerol allowing full promoter de-repression was determined with $\mathrm{q}_{\mathrm{s} \text { glycerol }}=0.054 \mathrm{~g} \mathrm{~g}^{-1} \mathrm{~h}^{-1}$. However, maximum productivity could only be achieved in a rather small operating window of $\mathrm{q}_{\mathrm{s} \text { glycerol, which }}$ underlines the importance of precise and robust process control.

- Sorbitol did not repress the mutated AOX1 derepression promoter. The maximum specific substrate uptake rate of this strain for sorbitol was determined with $\mathrm{q}_{\mathrm{s} \text { sorbitol }}=0.197 \mathrm{~g} \mathrm{~g}^{-1} \mathrm{~h}^{-1}$, where also highest productivity was reached.

- An easy-to-perform pulse experiment showed that the yeast strain was able to take up both glycerol and sorbitol concomitantly and revealed maximum $\mathrm{q}_{\mathrm{s}}$ values for both substrates.

- The highest productivity was reached at a ratio of $\mathrm{q}_{\mathrm{s} \text { glycerol }}$ to $\mathrm{q}_{\mathrm{s} \text { sorbitol }}$ of 0.7 . In this study, we were able to boost the productivity more than 2 -fold in the mixed feed environment compared to the commonly used single substrate strategy, where we fed glycerol in de-repressing conditions.

Summarizing, we have employed a methodological approach based on dynamic experiments to establish a mixed-feed strategy for a recombinant $P$. pastoris de-repression strain comprising three phases (1) batch, (2) repressed fed-batch at high $\mathrm{q}_{\mathrm{s} \text { glycerol }}$ and (3) de-repressed mixed feed fed-batch at a ratio $\mathrm{q}_{\mathrm{s} \text { glycerol }}$ to $\mathrm{q}_{\mathrm{s} \text { sorbitol }}$ of 0.7 . Based on our results we recommend adjusting $\mathrm{q}_{\mathrm{s} \text { glycerol }}=0.04 \mathrm{~g} \mathrm{~g}^{-1} \mathrm{~h}^{-1}$ and $\mathrm{q}_{\mathrm{s} \text { sorbitol }}=0.055 \mathrm{~g} \mathrm{~g}^{-1} \mathrm{~h}^{-1}$ to obtain highest productivity. Our methodological approach of designing mixed-feed strategies based on physiological strain characterization using dynamic experiments proved to be beneficial.

\section{Additional files}

Additional file 1: Figure S1. Dynamic fed-batch on glycerol as sole carbon source (FB1). The carbon dioxide evolution rate signal (CER, continuous black line) was used to follow metabolic activity. The specific glycerol uptake rate $\left(\mathrm{q}_{\text {s glycero }}\right)$ is depicted as continuous red line.

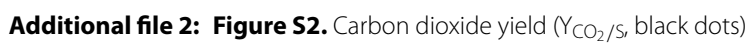
and biomass yield ( $Y_{X / s}$, white squares) at different specific glycerol uptake rates $\left(\mathrm{q}_{\mathrm{s} \text { glycerol }}\right)$.

Additional file 3: Figure S3. Volumetric productivity $\left(r_{p}\right)$ at different specific glycerol uptake rates $\left(\mathrm{q}_{\mathrm{s} \text { glycerol }}\right)$.

Additional file 4: Figure S4. Specific productivity $\left(q_{p}\right)$ at different specific glycerol uptake rates $\left(\mathrm{q}_{\mathrm{s}}\right.$ glycero $)$.

Additional file 5: Figure S5. Dynamic fed-batch on sorbitol as sole carbon source (FB3). The carbon dioxide evolution rate signal (CER, continuous black line) was used to follow metabolic activity. The specific sorbitol uptake rate $\left(\mathrm{q}_{\mathrm{s} \text { sorbitol }}\right)$ is depicted as continuous red line.

Additional file 6: Figure S6. Carbon dioxide yield $\left(\mathrm{Y}_{\mathrm{CO}_{2} / s_{s}}\right.$ black dots) and biomass yield ( $\mathrm{Y}_{\mathrm{X} / \mathrm{s}}$, white squares) at different specific sorbitol uptake rates $\left(q_{s}\right.$ sorbitol $)$.

Additional file 7: Figure S7. Volumetric productivity $\left(r_{p}\right)$ at different specific sorbitol uptake rates $\left(\mathrm{q}_{\mathrm{s} \text { sorbito }}\right)$.

Additional file 8: Figure S8. Specific productivity $\left(q_{p}\right)$ at different specific sorbitol uptake rates $\left(\mathrm{q}_{\mathrm{s} \text { sorbito }}\right)$.

\section{Authors' contributions}

OS panned the study, SC and JH conducted experiments. SC, JH and OS analyzed the data and wrote the manuscript. $\mathrm{CH}$ and OS supervised research and conceived of the study. All authors read and approved the final manuscript.

\section{Acknowledgements}

The authors thank the Austrian Science Fund FWF (project P24861-B19) for funding and VTU Technology GmbH (Grambach, Austria) for providing the new generation recombinant de-repression strain.

\section{Compliance with ethical guidelines}

\section{Competing interest}

The authors declare that they have no competing interests.

Received: 7 May 2015 Accepted: 25 June 2015

Published online: 10 July 2015

\section{References}

1. Ahmad M et al (2014) Protein expression in Pichia pastoris: recent achievements and perspectives for heterologous protein production. Appl Microbiol Biotechnol 98(12):5301-5317

2. Niu H et al (2013) A quantitative study of methanol/sorbitol co-feeding process of a Pichia pastoris Mut(+)/pAOX1-lacZ strain. Microb Cell Fact 12:33

3. Jungo C et al (2007) A quantitative analysis of the benefits of mixed feeds of sorbitol and methanol for the production of recombinant avidin with Pichia pastoris. J Biotechnol 131(1):57-66

4. Zhang WH et al (2003) Pichia pastoris fermentation with mixed-feeds of glycerol and methanol: growth kinetics and production improvement. J Ind Microbiol Biotechnol 30(4):210-215

5. Brierley RA et al (1990) Fermentation development of recombinant Pichia pastoris expressing the heterologous gene: bovine lysozyme. Ann NY Acad Sci 589:350-362

6. Jorda J et al (2013) Glucose-methanol co-utilization in Pichia pastoris studied by metabolomics and instationary (1)(3)C flux analysis. BMC Syst Biol 7:17 
7. Zalai D et al (2012) A dynamic fed batch strategy for a Pichia pastoris mixed feed system to increase process understanding. Biotechnol Prog. doi:10.1002/btpr.1551

8. Hartner FS et al (2008) Promoter library designed for fine-tuned gene expression in Pichia pastoris. Nucl Acids Res 36(12):76

9. Vogl T, Glieder A (2013) Regulation of Pichia pastoris promoters and its consequences for protein production. N Biotechnol 30(4):385-404

10. Vogl T et al (2014) Synthetic core promoters for Pichia pastoris. ACS Synth Biol 3(3):188-191

11. Mellitzer A et al (2014) Synergistic modular promoter and gene optimization to push cellulase secretion by Pichia pastoris beyond existing benchmarks. J Biotechnol 191:187-195

12. Weinhandl Ket al (2014) Carbon source dependent promoters in yeasts Microb Cell Fact 13:5

13. Hough E et al (1989) High-resolution (1.5 A) crystal structure of phospholipase C from Bacillus cereus. Nature 338(6213):357-360

14. Dietzsch C, Spadiut O, Herwig C (2011) A fast approach to determine a fed batch feeding profile for recombinant Pichia pastoris strains. Microb Cell Fact 10:85

15. Dietzsch C, Spadiut O, Herwig C (2011) A dynamic method based on the specific substrate uptake rate to set up a feeding strategy for Pichia pastoris. Microb Cell Fact 10:14

16. Krainer FW et al (2012) Recombinant protein expression in Pichia pastoris strains with an engineered methanol utilization pathway. Microb Cell Fact $11: 22$
17. Wechselberger P, Sagmeister P, Herwig C (2013) Real-time estimation of biomass and specific growth rate in physiologically variable recombinant fed-batch processes. Bioprocess Biosyst Eng 36(9):1205-1218

18. Spadiut $O$ et al (2014) Quantitative comparison of dynamic physiological feeding profiles for recombinant protein production with Pichia pastoris. Bioprocess Biosyst Eng 37(6):1163-1172

19. Durban MA et al (2007) High level expression of a recombinant phospholipase C from Bacillus cereus in Bacillus subtilis. Appl Microbiol Biotechnol 74(3):634-639

20. Otnaess AB et al (1977) Some Characteristics of Phospholipase-C from Bacillus-Cereus. Eur J Biochem 79(2):459-468

21. Kurioka S, Matsuda M (1976) Phospholipase C assay using p-nitrophenylphosphoryl-choline together with sorbitol and its application to studying the metal and detergent requirement of the enzyme. Anal Biochem 75(1):281-289

22. El-Moghaz ANA (2010) Comparative Study of Salt Tolerance in Saccharomyces cerevisiae and Pichia pastoris Yeast Strains. Adv Biores 1:169-176

23. Daniels MJ, Wood MR, Yeager M (2006) In vivo functional assay of a recombinant aquaporin in Pichia pastoris. Appl Environ Microbiol 72(2):1507-1514

\section{Submit your next manuscript to BioMed Central and take full advantage of:}

- Convenient online submission

- Thorough peer review

- No space constraints or color figure charges

- Immediate publication on acceptance

- Inclusion in PubMed, CAS, Scopus and Google Scholar

- Research which is freely available for redistribution

Submit your manuscript at

www.biomedcentral.com/submit

C BioMed Central 